\title{
Creation Rest: Exodus 20:8-11 and the First Creation Account
}

\author{
MATTHEW HaYNeS (NORTH-WeSt UNIVERSiTY) \\ AND P. PAUl KrÜger (NORTh-WeSt UNIVERSITY)
}

\begin{abstract}
The focus of this article is the Sabbath commandment as it is expressed in Exod 20. A number of factors that contribute to its expression are examined: the place of the Decalogue in the life of Israel, the stipulations for proper Sabbath observance, and the reasoning and motivation that lie behind its keeping. Additionally, various facets of human life that mark the seventh day of creation are connected to specific terminology within the fourth commandment. The article concludes by arguing that the Sabbath commandment in Exodus, properly observed, is a picture of the seventh day of creation and that a desire to recover that situation motivates its keeping.
\end{abstract}

KEYWORDS: Rest; Creation; Sabbath; Exodus 20; Garden of Eden; Noah

\section{A INTRODUCTION}

This article attempts to define more clearly the Sabbath institution as it is presented in Exod 20:8-11. Its focus is on the relationship between the fourth commandment in Exod 20, the purpose of Israel in the Promised Land, and the shape of the seventh day of creation.

Three issues will be addressed in turn. Firstly there is the issue of the Sabbath commandment in Deut 5. Why consider the relationship between the first creation account and the Exod 20 commandment without spending an equal amount of energy investigating the Deut 5 account?

* Submitted: 23/06/2017; peer-reviewed: 03/11/2017; accepted: 01/03/2018. Matthew Haynes and P. Paul Krüger, "Creation Rest: Exodus 20:8-11 and the First Creation Account," OTE 31 no. 1 (2018): 90-113. DOI: https://doi.org/10.17159/2312-3621/2018/v31n1a6 
Secondly, the place of the Decalogue in the life of Israel needs to be understood. In this regard, we will consider: (a) the context in which the Decalogue was given to Israel at Sinai, (b) the purpose of the Decalogue in the mission of Israel, and (c) the motivational considerations underpinning Decalogue observance.

The final issues requiring attention are the particular features of the fourth commandment itself. Aspects requiring specific attention include (a) the command itself, (b) stipulations for its proper observance, (including an understanding of labour), and (c) the motivating factors that serve to empower observance.

The overall approach of this article will be to employ a literary reading, which engages the final form of the text. Emphasis is placed upon its grammatical features and ongoing narrative. Key words and theological concepts are examined in the contexts in which they appear along with their intertextual connections to other passages in the Pentateuch. All of this is done with a view to describing the overarching theological connection between creation on the seventh day and rest in the Sabbath.

\section{$1 \quad$ Genesis 2:1-3 and the two Sabbath Commandments}

While the Sabbath commandment is recorded in both Exod 20:8-11 and Deut 5:12-15, there are significant differences in their presentation. An examination of the Exod 20 account reveals strong intertextual links with Gen 2:1-3:

- The periods of work and resting described in Gen 2:2 run parallel to those in Exod 20:11a, c.

- The description of the finished created order, both the environment and its inhabitants, are described similarly in Gen 2:1 and Exod 20:11b.

- The sanctification of the 7th day, along with the rationale for its sanctification, is depicted in Gen 2:3 and Exod 20:11d.

- עשה ("do" or "make") is used in both instances to describe God's creative activity (Gen 2:2, 3; Exod 20:11). It is also used to define the work prohibited by the Sabbath commandment in Exod 20:10. In both places מִלְאכָה ("work"). In Genesis it is God's work and in Exodus it is Israel's. ${ }^{1}$

1 Patrick Miller, The Ten Commandments (Louisville, KY: Westminster John Knox, 
Meanwhile, the emphasis of Deuteronomy's version of the Sabbath commandment lays in a different direction:

- While the primary commandment still relates to six days of work followed by one day of rest, a primary intertextual allusion within the commandment relates to the exodus event (Deut 5:15). Not only is Israel required to cease work one day in seven, but they are also required to remember what God has done for them.

- The Sabbath commandment in Deut 5 focuses on enumerating those who would gain benefit from the commandment. The extended list of those who should receive rest is emphasised. Israel's redemption from Egypt serves as a motivator in this regard. ${ }^{2}$

- Unlike the Sabbath commandment in Exod 20, the creation week is not directly addressed in Deut 5.

This is not to say that there are not significant overlaps between the two commandments. Significantly, both use the Hebrew term נוח to describe the rest of the seventh day. Both emphasise six days of work followed by a day of rest. Both describe the sanctification of the seventh day. Despite these overlaps, however, the stress of the commandment in Deut 5 lies in a different direction. Redemption and its implications for life in the Promised Land loom large in Deut 5. Nowhere is the notion of redemption reflected in the language of Exod $20 .^{3}$ It is for this reason that the present article is restricted to the Sabbath commandment as it is articulated in Exod 20.

\section{B THE PLACE OF THE DECALOGUE IN THE LIFE OF ISRAEL}

The grand narrative of the Bible can be described as a play with four primary movements: creation, fall, redemption, and consummation. ${ }^{4}$ The overarching story portrays God's actions as driven by specific goals. God worked in an orderly manner, achieved specific ends, and then contentedly rested in his

2009), 124-25.

2 Asher Eder, "The Sabbath Commandment: Its Two Versions," JBQ 25/3 (1997): 188-91; Daniel Block, Deuteronomy, NIVAC (Grand Rapids: Zondervan, 2012), 164.

3 Recognising the differing emphasis in each commandment is not to say that there is no relationship between the Sabbath commandment in Deut 5 and creation. It is simply to recognise that it is attempting to elicit a more nuanced response on the part of the hearer. An investigation of those nuances, however, is beyond the scope of this article.

4 Michael Williams, Far as the Curse is Found: The Covenant Story of Redemption (Phillipsburg, NJ: Presbyterian \& Reformed, 2005), xi. 
accomplishments. In the aftermath Genesis 3, with his image-bearers exiled from the garden, he sets about blessing and restoring humanity to his original intention. $^{5}$

\section{$1 \quad$ Israel at Sinai}

With God's promises to Abraham in Gen 12:1-3, we see these purposes begin to advance from the universality of humanity ${ }^{6}$ to the particularity of Israel. Within this context Israel's identity is shaped. YHWH's redemption of Israel from Egypt had horizons far beyond their freedom; ultimately, it was to advance God's intention to bless all of humanity through the seed of Abraham. There is correspondence between God's plans for humanity and the function of Israel within those plans. ${ }^{7}$ These plans are articulated in the statements that YHWH makes prior to giving Israel the Decalogue (and indeed the law as a whole). Exodus 19:4-6 stands as a juncture between narrative and law: ${ }^{8}$

${ }^{4}$ You yourselves have seen what I did to the Egyptians, and how I bore you on eagles' wings and brought you to myself. ${ }^{5}$ Now therefore, if you will indeed obey my voice and keep my covenant, you shall be my treasured possession among all peoples, for all the earth is mine;

${ }^{6}$ and you shall be to me a kingdom of priests and a holy nation.

Several things should be recognised about this text's placement in the Sinai narrative:

- It stands as background to the law. Why should they "keep my covenant" (i.e., obey the law)? They should keep it because YHWH redeemed them from slavery in Egypt. Furthermore, he explicitly states his purpose for doing so (v. 6).

- It underscores YHWH's declaration of ownership over all of creation. At the same time, Israel stands apart as something unique among the things that he owns. Thus they are described as a "treasured possession" (סְגְלְלה).

5 See Williams, Far as the Curse is Found, 271-302; and Albert Wolters, Creation Regained: Biblical Basics for a Reformational Worldview (Grand Rapids: Eerdmans, 2005), 69-86 for extended discussion on this point.

${ }^{6}$ As noted in Matthew Haynes and P. Paul Krüger, "Creation Rest: Genesis 2:1-3 and the First Creation Account," OTE 30/3 (2017): 663 -683.

7 Christopher Wright, The Mission of God (Downer's Grove, IL: Intervarsity, 2006), 224-25, 252-54, 328-56; Cf. Gen 12:3.

8 James Bruckner, Exodus (Peabody, MA: Hendrickson, 2008), 180; Wright, Mission, 330. 
94 Haynes \& Krüger, “Creation Rest,” OTE 31/1 (2018): 90-113

The term סְגִלְלה indicates (personal) "property"9 and appears in the OT only eight times - six making reference to Israel as God's possession (Exod 19:5; Deut 7:6; 14:2; 26:18; Ps 135:4; Mal 3:17). This is not general "property," however. It is the kind of property personally acquired and kept for special use. ${ }^{10}$ Hence, in the present context, Israel stands in contrast to "all peoples" and "all the earth" (v. 5b).

- The passage also describes the particular role that this unique position will require of Israel. They are intended to function as a priestly kingdom. At this point it should be remembered that, within Israel, a priest's work was bi-directional. On the one hand, a priest was responsible for teaching the law and thus bringing the knowledge of God to the people (Lev 10:11; Deut 33:11). On the other hand, he brought the people close to God by overseeing the sacrificial system (Lev 1-7). Wright notes,

It is thus richly significant that God confers on Israel as a whole people the role of being his priesthood in the midst of the nations. As the people of YHWH they would have the historical task of bringing the knowledge of God to the nations, and bringing the nations to the means of atonement with God. ${ }^{11}$

With respect to God's overall plan, and in particular for righting the problems introduced by Gen 3, Israel was intended to reflect seventh-day life and the means by which the nations could participate in that life. ${ }^{12}$ This unique work necessitated their status as a holy nation. Their faithfulness to this task (Exod 19:5) would stand in accordance with their election and fulfil God's promise to bless the nations through Abraham.

All this suggests that, within the context of Exod 19, faithfully keeping up the Decalogue was an integral part of Israel's function. Keeping the fourth commandment would display God's intentions at creation and the means by which the nations could participate in seventh-day living.

9 HALOT, 742.

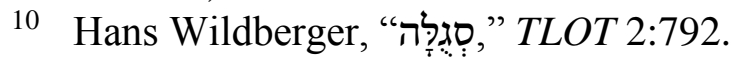

11 Wright, Mission of God, 331.

12 John Durham, Exodus, WBC 2 (Waco, TX: Word, 1987), 263; Wright, Mission of God, 330-31.; Cf. Deut 4:5-8. 


\section{The Decalogue and the Mission of Israel}

We can now begin to see how the law given at Sinai reflects the situation of the seventh day. As a reflection of creation, the law did three things: ${ }^{13}$

- It was a reminder to Israel concerning YHWH's creational intent for his image-bearers - the ideals by which humans should function within the created order.

- It charged them to strive towards that ideal. As a "kingdom of priests and a holy nation" (Exod 19:6) they bore witness to the nations that the world is not as it was intended to be. At the same time, in Israel they could see life as it was intended on the seventh day.

- The Decalogue sets itself as the standard by which all of humanity is bound. It was not something only for the nation of Israel. As precepts rooted in the seventh day, it is the obligation of all of humanity.

There was never a time when the first commandment (putting God first) was not God's will for man. Nor will there be a time in the future when the sixth commandment (the prohibition against murder) will no longer be God's will. ${ }^{14}$

In its position between the preamble of Exod 19 and the specific laws described in the Book of the Covenant (Exod 21-23), the Decalogue stands as the starting point for the law. ${ }^{15}$ While its commandments are imperatives, they are apodictic laws, whereas many of the laws that follow are casuistic laws, referring to the application of principles to different cases or situations. Many of the laws contained in the Book of the Covenant, for example, are written and received by unidentified parties. Exodus 22:14: "If a man borrows anything of his neighbour, and it is injured or dies, the owner not being with it, he shall make full restitution." At the same time, the Decalogue is written in a way highlighting the unique relationship between YHWH and Israel. The prologue makes this clear when it says, "I am the Lord your God, who brought you out of the land of Egypt, out of the house of slavery." Furthermore, the Decalogue does not focus upon specific penalties for failure to keep its commands. Instead, the results of obedience or disobedience are discussed in terms of the relationship between

13 Williams, Far as the Curse is Found, 157-59.

14 Williams, Far as the Curse is Found, 159.

15 Patrick Miller, "The Place of the Decalogue in the Old Testament and its Law," Int 43/3 (1989): 230. 
YHWH and Israel. ${ }^{16}$ Thus the second commandment concludes with: “. . . visiting the iniquity of the fathers on the children to the third and fourth generation of those who hate me, but showing steadfast love to thousands of those who love me and keep my commandments" (Deut 9-10). This suggests that these commands are foundational in nature. They are the basic principles upon which the law is built and can be applied in various ways to specific circumstances as conditions warrant.

The Decalogue's foundational nature is seen in its (a) structure and (b) the way it is used by other OT texts. Structurally, it begins with Israel's obligations to YHWH and then moves on to her obligations to neighbour. The relational nature commandments are seen throughout. Israel's redemption from Egypt not only forms the backdrop to the relationship between God and Israel found in the first four commandments, but it is also the basis of her responsibility to her neighbour. The two tables of the Decalogue are not so easily bifurcated; to keep covenant properly with God, Israel had to fulfil her relational obligations to her neighbour as well. ${ }^{17}$ Not only is murder a transgression against humanity, but a transgression against YHWH as the giver and owner of life.

Miller ${ }^{18}$ describes the ways in which the Decalogue's foundational nature can be seen in the ways that it is referenced by other OT texts:

- The OT summarises the Decalogue at other points. Particularly, at the heart of the Shema (Deut 6:4-5), we find, "You shall love the Lord your God with all your heart and with all your soul and with all your might." Allusion is then made to the Shema throughout the OT. The NT picks it up as well. In Mark 12:28-31 (and par.) Jesus is asked, "Which commandment is the most important of all?" He responds with Deut 6:5. In addition to the Shema, other OT passages also summarise portions of the Decalogue. Leviticus 19:3-4, for instance, reflects aspects of the first, second, fourth, and fifth commandments. Other partial summaries can be found in Pss 50 and 81.

- The Decalogue finds elaboration in the specific legal codes of the OT. Exodus 20:23, builds on the first and second commandments, specifying forms that are prohibited: "You shall not make gods of silver to be with me, nor shall you make for yourselves gods of gold." Exodus 23:24 adds actions to be taken against false gods in addition to the prohibition of worship: "you shall not bow down to their gods nor serve them, nor do as

16 Miller, "Place of the Decalogue," 232.

17 Miller, "Place of the Decalogue," 232-33.

18 Miller, "Place of the Decalogue," 234-42. 
they do, but you shall utterly overthrow them and break their pillars in pieces." Further laws defining proper Sabbath observance occur as well. Exodus 35:1-3 specifies the penalty for breaking it: “. . . Whoever does any work on it shall be put to death. You shall kindle no fire in all your dwelling places on the Sabbath day." Additional elaborations are found in Exod 23:12; 31:12-17; 34:21; 35:1-3; Lev 19:3; 23:3; and 26:2.

- Finally, every commandment in the Decalogue inaugurates a movement that gives direction to community life beyond the commandment itself. For example, while the fourth commandment specifies rest only on the seventh day, both Exodus and Leviticus expand the notion further. In the context of Sabbath stipulations, Exod 23:10-14 describes leaving land fallow once every seventh year. Similarly, Lev 25:2-8 repeats the regulation of Exod 23:10-14 but further describes it as "a Sabbath of solemn rest for the land." This is then further expanded in laws surrounding the year of Jubilee (Lev 25:8-17); not only was the land allowed to lie fallow but indentured servants were to be set at liberty as well. ${ }^{19}$

\section{$3 \quad$ Motivational considerations}

From the preceding section it might appear that obedience to the Decalogue is first and foremost an external matter, with no real requirement for internalisation. Childs notes this "apparent unconcern" for inner motivation and argues that internalisation "stands on the edge of the commandments". ${ }^{20}$ The Shema in Deut 6 makes this clear. Furthermore, the NT picks up on the same theme when Paul says in Rom 2:28-29:

\footnotetext{
${ }^{28}$ For no one is a Jew who is merely one outwardly, nor is circumcision outward and physical. ${ }^{29}$ But a Jew is one inwardly, and circumcision is a matter of the heart, by the Spirit, not by the letter.
}

Proper covenant fidelity is not fulfilled simply with external adherence. Covenant faithfulness, rather, begins in the heart and moves outwards toward OT law as the rule of life externally displaying love of God and love of neighbour. ${ }^{21}$ In this, Paul is restating a theme that is well known in the OT and commonly referred to as the "circumcision of the heart."

19 Jay Sklar, Leviticus, TOTC 3 (Downers Grove, IL: Intervarsity, 2014), 300.

20 Brevard Childs, Exodus: A Commentary (London: SCM, 1974), 396.

21 Matthew Black, Romans: Based on the Revised Standard Version (Grand Rapids: Eerdmans, 1973), 52; C. John Collins, Recurring Biblical-Theological Issues in OT 
In the context of Moses' second address to Israel, prior to their entry into the Promised Land, he warns: "Circumcise therefore the foreskin of your heart, and be no longer stubborn" (Deut 10:16). He goes on to remind them to be careful to follow the law once they have entered the Promised Land (Deut 4-6), pointing out that there is nothing inherent within themselves that would cause YHWH to choose them (Deut 7-8) and that they have failed in the past (Deut 9:13-29). These failures are indicative of an internal disposition - they require heartcircumcision to keep covenant properly with YHWH; attempts at simple adherence to the law will not suffice. YHWH requires their affectionate devotion as well:

\begin{abstract}
And now, Israel, what does the Lord your God require of you, but to fear the Lord your God, to walk in all his ways, to love him, to serve the Lord your God with all your heart and with all your soul . . . (Deut 10:12).
\end{abstract}

Thus external covenant-keeping should reflect inner disposition. ${ }^{22}$ The same concept is also reflected in Deut 30:6, Jer 4:4, and 9:25-26. It was "not the outward claim, or the ordinances of the covenant" that made Israel "a true partaker of the covenant's promises - but a living faith expressing itself in love and obedience." 23

Moses' call to Israel to "keep the commandments and statutes of the Lord" (Deut 10:13) springs from YHWH's past action on their behalf and Israel's response of love. ${ }^{24}$ The Decalogue in Exod 20 reflects a similar situation. Israel's motivation for covenant obedience springs from YHWH's past action on their behalf. ${ }^{25}$ Some scholars understand the statement of Exod 20:2 as a covenant document prologue spelling out a king's favour and historical work: "I am the Lord your God, who brought you out of the land of Egypt, out of the house of slavery." 26 Israel's required response to this redemptive act was to love YHWH for what he had done manifesting that love in faithful covenant keeping.

Studies (Unpublished, 2005), 1, 5; David VanDrunen, Divine Covenants and Moral Order: A Biblical Theology of Natural Law (Grand Rapids: Eerdmans, 2014), 250.

22 Patrick Miller, Deuteronomy, IBC (Louisville, KY: John Knox, 1990), 125-127; Duane Christensen, Deuteronomy 1:1-21:9, rev. ed. (Nashville, TN: Thomas Nelson, 2001), 206; J. Gordon McConville, Deuteronomy, ApOTC 5 (Downer's Grove, IL: Intervarsity, 2002), 200.

23 Collins, Recurring, 2.

24 Chris Wright, Old Testament Ethics for the People of God (Downer's Grove, IL: Intervarsity, 2004), 40.

25 Patrick Miller, Ten Commandments, 16.

26 Williams, Far as the Curse is Found, 141. 
The result of this inward disposition would be their identification as YHWH's treasured possession who act as a kingdom of priests (Exod 19:5-6).

\title{
C EXODUS 20:8-11
}

We now come to Exod 20:8-11, the heart of the present article:

\begin{abstract}
${ }^{8}$ Remember the Sabbath day, to keep it holy. ${ }^{9}$ Six days you shall labor, and do all your work, ${ }^{10}$ but the seventh day is a Sabbath to the Lord you God. On it you shall not do any work, you, or your son, or your daughter, your male servant, or your female servant, or your livestock, or the sojourner who is within your gates. ${ }^{11}$ For in six days the Lord made heaven and earth, the sea, and all that is in them, and rested on the seventh day. Therefore the Lord blessed the Sabbath day and made it holy.
\end{abstract}

The commandment divides itself into three sections. ${ }^{27}$ First comes the command itself (v. 8). Second are (vv. 9-10) stipulations for proper observance. Finally, the reasoning and motivation are described in $\mathrm{v} .11$.

\section{The Sabbath Command}

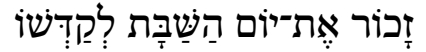

"Remember the Sabbath day to keep it holy" (Exod 20:8).

Here, שבת is used as a proper noun to name the seventh day; the name itself provides guidance concerning the shape of the day. The primary idea of שבת is cessation. ${ }^{28}$ Therefore, the Sabbath is to be a day of cessation. ${ }^{29}$ Almost all commentators ${ }^{30}$ connect the "Sabbath" day to the verb שבת, but there is no similar consensus concerning the concept's origin and development. ${ }^{31}$

27 Peter Enns, Exodus, NIVAC (Grand Rapids: Zondervan, 2000), 418.

28 Haynes and Krüger, "Creation Rest: Genesis 2:1-3," 666-667.

29 Durham, Exodus, 289; Douglas Stuart, Exodus: An Exegetical and Theological Exposition of Holy Scripture, NAC 2 (Nashville, TN: Broadman \& Holman, 2006), 458.

30 E.g., Victor Hamilton, "שבת,," TWOT 2:902; Durham, Exodus, 289; Stuart, Exodus, 458.

31 See Hamilton, TWOT, 2:902-903 for a discussion of the development of the nominal form of שבת and its possible origins. Roland de Vaux, Ancient Israel and Its Life and Institutions (London: Darton, Longman \& Todd, 1961), 475-480, while now dated, discusses options still currently held concerning the origin and development of the 
זָכוֹר infinitive an absolute, begins the verse and underscores the importance of the verb ${ }^{32}$ — emphasis is laid on Israel's responsibility to remember. Strong negations are used in other commandments (lo + impf. vs. ' $a l$ + imper.), and the use of the infinitive absolute highlights a commandment where a simple imperative would normally be expected otherwise. It carries the weight of an injunctive future: remembering is something that Israel must do. ${ }^{33}$ Remembering is not merely a mental act; there are attendant external actions as well. Both the mental act and the external action are required for true remembrance to occur. ${ }^{34}$

There are covenantal overtones as well. When זכר is used with God as the subject it describes a situation in which he is about to act on behalf of the object of his divine remembering and often indicates his favourable disposition. ${ }^{35}$ In

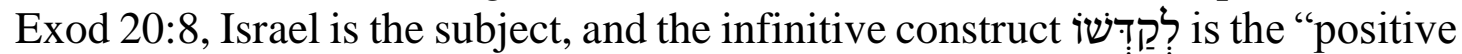
counterpart" 36 to זٓזכוֹר , describing the purpose for Israel's remembrance of the day. Other examples where humanity is the subject of זכר in covenant contexts are Exod 13:3, Amos 1:9, and Ps 106:7. When Israel is properly remembering the Sabbath, their cognitive recognition of the day incites them to set it apart as something holy and different from the other six days. ${ }^{37}$ Stated differently, only when Israel sets the day apart from all others as YHWH's unique possession does true remembrance occur. ${ }^{38}$ Later, YHWH describes the fourth commandment as the "sign" of the covenant between himself and Israel (Exod 31:12-17): an outward and visible symbol that represents (a) his relationship with his treasured possession and (b) the benefits attendant to that relationship. Setting apart the Sabbath from other days indicates the inward disposition of the people towards the covenant as a whole. Its placement at the end of the commandments relating specifically to God makes sense - it serves to differentiate the seventh day from all others, but it also encapsulates everything that has gone before. Israel's intentionality in keeping the Sabbath was a barometer of her inward disposition towards YHWH and gave an indication of whether or not she was keeping the first three commandments as well.

\footnotetext{
Sabbath institution within Israel.

32 See Allen Ross, Introducing Biblical Hebrew (Grand Rapids: Baker Academic, 2001), §23.2, who cites this passage as an example.

33 Paul Joüon and Takamitsu Muraoka, A Grammar of Biblical Hebrew, 2nd ed.

(Rome: Gregorian \& Biblical Press, 2011), 343-44, 399.

34 Thomas McComiskey, "זכר," TWOT 1:241; Enns, Exodus, 418.

35 See, for example, Gen 8:1; 9:15, 16; 19:29; 30:22; Exod 2:24; 6:5; 1 Sam 1:19.

36 Joüon and Muraoka, Grammar, 343.

37 Enns, Exodus, 418.

38 Stuart, Exodus, 458.
} 


\section{Stipulations for proper observance}

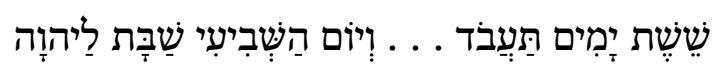

"Six days you will labour . . . but the seventh day is a Sabbath to YHWH” (Exod 20:9-10a).

The second element pairs the cognitive aspect of remembering introduced in v. 8 with explicit stipulations. Six days are allowed for work, but the seventh day is marked by a cessation of work. Not only are the Israelites themselves required to stop their labour, but the commandment is extended to children, slaves, and even as far as the livestock and foreigners who reside within their borders. Several issues need to be addressed to clarify what proper observance of these stipulations entails. First, what exactly is the labour that the commandment prohibits? Second, how does this labour relate to the first creation account? Finally, why does the fourth commandment go to the lengths it does to define the breadth of its applicability?

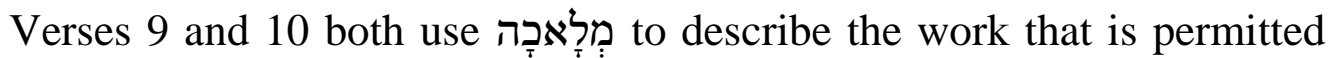
during the first six days but prohibited on the seventh. מְלָ occurs in a number of different OT contexts and can refer to a particular undertaking or a regular business practice. The person doing the work does not matter; מִלָ can be accomplished by a menial labourer or a king. ${ }^{39}$ As it is linked to the work accomplished during the six days, it is best seen as work associated with an occupation or business. Interestingly, the same word describes God's work in Gen 2:2, 3. Durham ${ }^{40}$ describes this labour as "customary" and further says it "refers to the daily work of one's occupation, and also to what might be called the labour of sustenance." ${ }^{.11}$ This leads to our second question. If the labour being referred to in the Sabbath commandment is primarily the customary labour of an occupation, how does that relate to the first creation account?

The fourth commandment does not create the Sabbath as a new idea (cf. Exod 16:23); it codifies a practice that was already known at the time the fourth commandment was given. ${ }^{42}$ While the fourth commandment may be an outgrowth of the creation week, it is not a mandate of creation. The first creation

\footnotetext{
39 Stephen Hague, "מִלָָָּּ," NIDOTTE, 943.

40 Durham, Exodus, 276.

41 So also Stuart, Exodus, 459.

42 Carl Keil, The Pentateuch (Peabody, MA: Hendrickson, 1866), 398; Bruce Waltke, An Old Testament Theology: An Exegetical, Canonical, and Thematic Approach (Grand Rapids: Zondervan, 2007), 420.
} 
account speaks only about God's rest on the seventh day. The expansive rest described by the fourth commandment is not something reflective of the seventh day itself. Or is it? Has something changed since Gen 2:1-3 that would affect the function given to humanity in Gen 1:26-28? If so, is there anything that would connect that change to the fourth commandment? Genesis 5:29 provides an indication that there is an affirmative answer to both questions.

Genesis 5:29 comes near the end of the first extensive genealogical account in Genesis and records the family line from Adam to Noah. When Lamech names his son Noah (j), he says, "Out of the ground that the Lord has

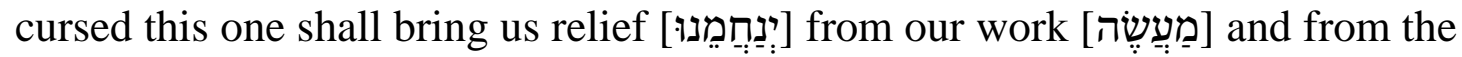

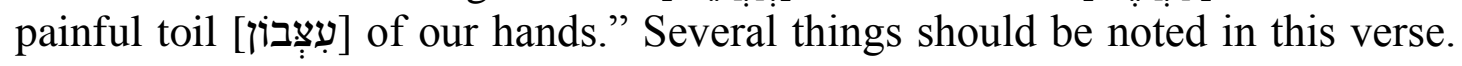
First, he calls his son Noah, a name whose meaning is closely associated with the Sabbath stipulation in the fourth commandment; the same verbal root (נוח) is used in Exod 20:11 to describe YHWH's rest on the seventh day. Second, Lamech makes reference to the events of Gen 3. Highlighting this is Lamech's use of עִצְבוֹן ("painful toil"), the same descriptor used by God when he curses

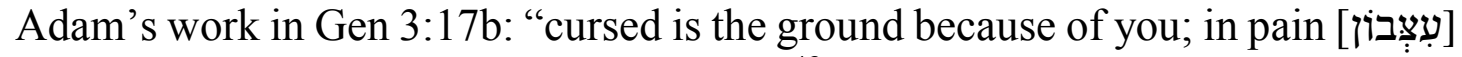
you shall eat of it all the days of your life." 43 Finally, he expresses his desire for a change in the working conditions that have prevailed since Adam and Eve's expulsion from the garden.

The relief from work and painful toil that Lamech is seeking stems from the curse that YHWH placed upon Adam in Gen 3:17-19. ${ }^{44}$ Genesis 3:1-13 describes how Adam disobeyed God's instruction not to eat from the fruit of the tree of the knowledge of good and evil. While some take Gen 3:17-19 to be a curse upon both Adam and creation itself, this is not something the text itself asserts. $^{45}$ The curse (Gen 3:17b-19a) is directed at Adam and specifically involves the arena in which he will exercise his primary labour, the ground

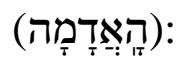

... cursed is the ground because of you; in pain you shall eat of it all the days of your life; thorns and thistles it shall bring forth for you; and you shall eat the plants of the field. By the sweat of your face you shall eat bread...

43 David Beakley, "God's nḥm ('Comfort') as the Unfolding of God's Promise in Four Old Testament Historical Passages” (PhD diss., North-West University, 2014), 129.

44 Claus Westermann, Genesis 1-11: A Commentary, trans. John J. Scullion (Minneapolis, MN: Augsburg, 1984), 359; Wright, Old Testament Ethics, 131, 154; C. John Collins, Genesis 1-4: A Linguistic, Literary, and Theological Commentary (Phillipsburg, NJ: Presbyterian \& Reformed, 2006), 164.

45 Collins, Genesis 1-4, 164. 
While the curse does change the inner workings of creation, ${ }^{46}$ there is an effect on the environment. As participants in the sphere in which Adam works, both the livestock and ground are affected to some extent. The creation accounts suggest that Adam and Eve were to extend the borders of the garden in the course of fulfilling their mandate to be fruitful and multiply. Now they will be removed from the garden and the work of their mandate will have to be executed outside the garden as well, becoming toilsome and painful. ${ }^{47}$

Lamech is lamenting the weight of this situation when he names his son Noah. Noah (j) is is associated with the Hebrew term whe same word used in the rest stipulation of the fourth commandment. ${ }^{48}$ As we will see below, נוח describe "rest" that is characterised by a state of settlement in a stable environment marked by safety and security. Lamech explains the name himself, saying, "this one shall bring us relief ... "49 Some discussion surrounds the use ינֵּחמֵנוּ (comfort, relief) in the verse. A few scholars have suggested that the text should be emended to the hip "il form of "he will cause to rest." "50 They do so because the LXX translates with $\delta$ Lv $\alpha \pi \alpha v$ $\sigma \varepsilon 1$ ("to allow to rest for awhile") 51 which presupposes the hip 'il stem. While the change may seem appropriate as an explanation for Noah's name, there are no textual variations in the MT at this point supporting the LXX change. ${ }^{52}$ While changing the verb form would make the connection to the fourth commandment even more explicit, it is not required to sustain the point. Lamech would like the kind of relief offered by the fourth commandment, and his desire is reflected in the name that he gives to his son. ${ }^{53}$

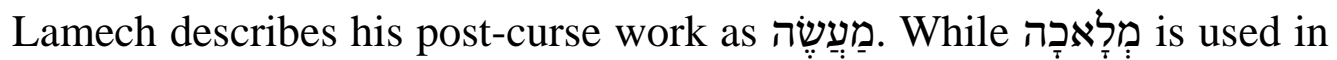

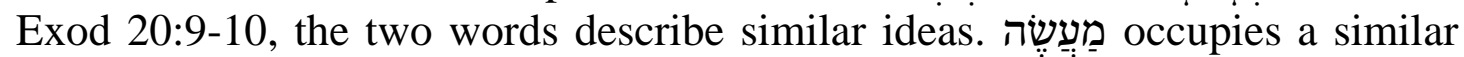
semantic field to the customary labour described in the fourth commandment: a

46 As suggested by the more restrictive term אָדָמָה "ground" rather than the broader term "world/earth" that is used to speak of creation more widely. See Wright, Old Testament Ethics, 131.

47 Collins, Genesis 1-4, 165.

48 As noted above, it is the primary word for rest used in both Exod 20 and Deut 5. Keil, Pentateuch, 80; Westermann, Genesis 1-11, 360; John Walton, Genesis, NIVAC (Grand Rapids: Zondervan, 2001), 281.

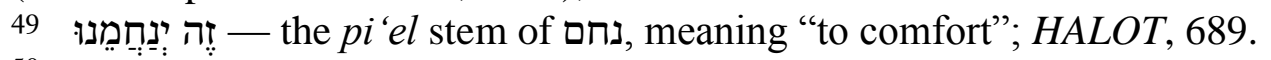

50 George Berry, "The Hebrew Word Iנוּ," JBL 50/3 (1931): 209; Westermann, Genesis 1-11, 360.

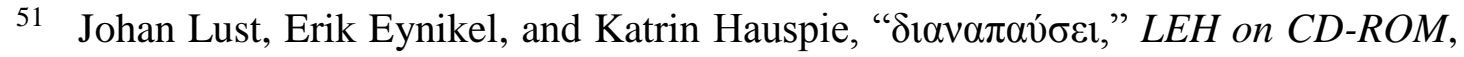
par. 8036.

52 An extended discussion of the merits of this emendation can be found in Emil Kraeling, "The Interpretation of the Name of Noah in Gen. 5:29," JBL 48/3-4 (1929): 138-43.

53 For an extended discussion of the relief Lamech seeks and its relationship to the curse of Genesis 3, see Beakley, "God's nhm," 126-32. 
"labour, work(ing), task, occupation, trade, business." "54 Swanson provides a bit more nuance, suggesting that מַעְשֵֶׁ focuses on the energy that is expended in the

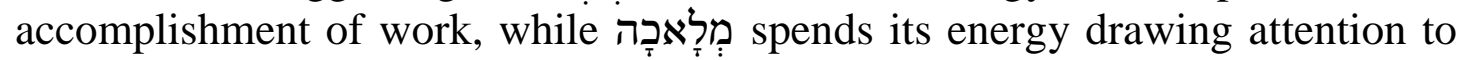
the work itself. Even so, the difference is slight, and Swanson attributes both to the same semantic field. ${ }^{55}$ It is used as such to describe customary labour in Judg 19:16 and Hag 2:17. However, it is found in Sabbath contexts as well. Ezekiel 46:1 begins a section that gives instructions for following the weekly Sabbath and monthly new moon: "Thus says the Lord God: The gate of the inner court that faces east shall be shut on the six working days, but on the Sabbath day it

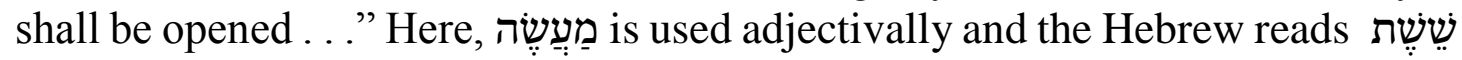

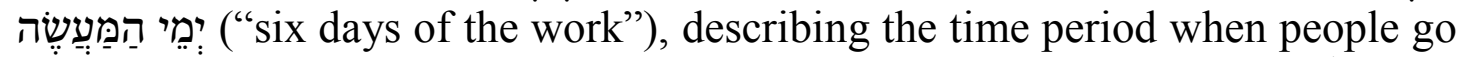
about their customary labour. If this is not enough to suggest that מִלְ מִכָ and מַעַשֶׁה should be understood to mean the same thing in Sabbath contexts, then

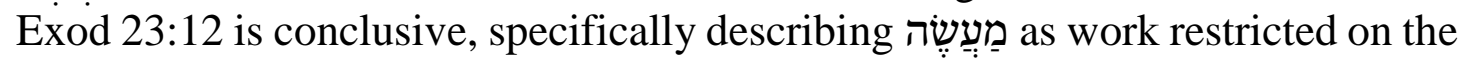

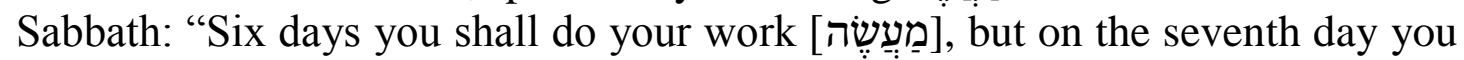
shall rest."

Several things should be noted concerning these connections. First, the overlap in terminology suggests that there is an agreement of ideas: (a) the rest Lamech is seeking is the same kind of rest that is spoken about in the fourth commandment; (b) the work Lamech laments is the same kind of work described by the fourth commandment. Second, Lamech's plea implies that there is a certain kind of work from which he is seeking relief. He is not necessarily seeking relief from all labour, but he is rather seeking relief from curse-ridden work. Finally, Noah never accomplished the aspirations that Lamech had for him. Some scholars suggest that the relief that Noah brought was the introduction of viticulture. ${ }^{56}$ While that may be a type of relief, the use of terms that later become so prevalent in the context of the fourth commandment indicates that the relief grape and wine production bring to curse-fraught work is not the final solution that Lamech is seeking. ${ }^{57}$ Lamech wants Adam's curse lifted from his own work. Wright, speaking on Gen 5:29, comments, "The consistent biblical hope, from Genesis to Revelation, is that God should do something with the earth so that we can once again dwell upon it in 'rest,' in Sabbath peace, with him." 58

$54 \mathrm{CDCH}, 236$.

55 Swanson, James, "מַעַשֶׁ," DBL on CD-ROM.

56 Westermann, Genesis 1-11, 360; Bruce Waltke, Genesis: A Commentary (Grand Rapids: Zondervan, 2001), 147.

57 Kraeling, "Interpretation," 141.

58 Wright, Old Testament Ethics, 154. For further discussion on the Noahic covenant and its application to seventh-day life in the garden, see Wright, Old Testament Ethics, 132-37. or VanDrunen, Divine Covenants, 95-132. Further discussion of Noah as a second Adam and the flood as a recreation of Gen 1 - further strengthening Noah's ties to the fourth commandment - can be found in Waltke, Old Testament Theology, 290-97. 
[Our emphasis, M.H. \& P.P.K.] All of this is suggestive: the rest required by the fourth commandment does not necessarily entail the absence of all work, but rather the absence of a certain kind of work - it is the cessation of work marred by the curse levied in Gen $3 .{ }^{59}$ On a functional level, there was no aspect of Israel's daily occupational labour that would fall outside of the fourth commandment's purview as all humanity continued to labour under the effects of the Gen 3 curse.

Recognising that the fourth commandment requires the stoppage of curseridden work augments the purpose behind its generously broad application. Those specifically covered by the commandment include "you, or your son, or your daughter, your male servant, or your female servant, or your livestock, or the sojourner who is within your gates." The waw connecting each member of this list is an "alternative" use of the conjunction and serves to compile terms that extend the prohibition beyond the first referent listed. ${ }^{60}$ This alternative use of the waw signals the notional relation of "inclusive disjunctives," where the terms mentioned serve as specific instances of a generic concept. ${ }^{61}$ The commandment applies to individual Israelites, but all Israelites are further responsible for ensuring that the listed entities underneath their authority have the freedom to enjoy Sabbath rest as well.

This extensive application is rooted in the function of Israel as God's kingdom of priests and the purpose of the law itself. As suggested above, the events at Sinai and the law itself look back to the state of humanity on the seventh day. Israel's life in the Promised Land was intended to be a reordered garden experience in the midst of the nations who no longer reflected seventh-day living. ${ }^{62}$ Thus the Exodus rationale for the Sabbath is connected to the larger experience of humanity because the need is shared by all humanity. ${ }^{63}$ Furthermore, the beneficiaries included in the Sabbath is intentional and no mere afterthought. The Book of the Covenant takes up the Sabbath commandment again in Exod 23:12 and reiterates that rest is for all:

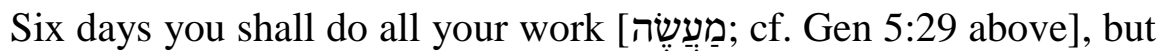
on the seventh day you shall rest [נוח]; that your ox and your donkey

\footnotetext{
59 Keil, Pentateuch, 399.

60 Cf. Ronald Williams, Williams' Hebrew Syntax, $3^{\text {rd }}$ ed. (Toronto: University of Toronto Press, 2007), 153.

61 Cf. Peter Cotterell and Max Turner, Linguistics and Biblical Interpretation (Downers Grove, IL: Intervarsity, 1989), 208-9.

62 Enns, Exodus, 419.

63 Miller, Ten Commandments, 124.
} 
may have rest [נוח], and the son of your servant woman, and the alien, may be refreshed. ${ }^{64}$

Therefore Sabbath rest is not restricted to people who are Israelites or who are free or who are heads of households. It is not even restricted to humanity, because those creatures that are employed by humankind to share the burden of curse-ridden work also need rest as they labour under the effects of the curse. Indeed, eventually even the land itself will benefit from the Sabbath principle since the cultivated land also suffers due to the curse-ridden work and even exploitation performed by humankind (Exod 23:10-11; Lev 25). This rationale is further clarified in the following verse (v. 12).

\section{$3 \quad$ Reasoning and motivation}

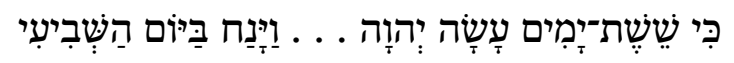

"for in six days YHWH made ... and he rested on the seventh day" (v. 11).

The commandment as a whole. ${ }^{65}$ The Sabbath is reflective of YHWH's activity in creation. As the purpose of God's creational activity is the rest that marks the seventh day, so this rest finds prominent status in the fourth commandment as well. ${ }^{66}$ As we saw above, at the time Israel entered the Promised Land all of humanity laboured under the effects of the curse pronounced by God in Gen 3. Thus the total intentions of God for humanity at the conclusion of the creation week - the situation of the seventh day and the rest portrayed on it - is no longer the experience of humanity. By motivating for a day without the normal labour which marks human existence and connecting that day with the seventh day of creation God is, in effect, offering a small taste of what the seventh day was meant to embody.

64 Miller, Ten Commandments, 122.

65 Childs, Exodus, 414.

66 See Matthew Haynes and Paul Krüger, "Creation Rest: Genesis 2:1-3 and the First Creation Account," OTE 30/3 (2017): 663-83, who argue that the whole point of the first creation account is the rest of God which marks the seventh day. Additionally, while God rested, humanity shared in that "rest" by carrying out their appointed tasks of subduing the earth, exercising dominion, and expanding the borders of the Garden of Eden. 
Scholars ${ }^{67}$ have long recognized an echo of the first creation account in the commandment:

And on the seventh day God finished his work that he had done, and he rested on the seventh day from all his work that he had done. So God blessed the seventh day and made it holy, because on it God rested from all his work that he had done in creation.
For in six days the Lord made heaven and earth, the sea, and all that is in them, and rested on the seventh day. Therefore the Lord blessed the Sabbath day and made it holy.

The terminology differs slightly from Gen 2 to Exod 20. Perhaps the most striking difference is the substitution of the שוח in Exod 20 for שבת in the first creation account. Chronologically one would expect the substitution to be made the other way around.

In his study of נוח, Robinson ${ }^{68}$ notes that scholars "who deny the rest-idea to $s b t$... take $n w h$ to be the proper root to express the idea of rest in the OT". He demurs, arguing that the word's primary force is concerned with the cessation of motion. Any implied rest is the result of settling down from an agitated state. Others also take a view that is more nuanced than simple "rest." Coppes ${ }^{69}$ specifies that נוח marks an "absence of spatial activity." Oswalt ${ }^{70}$ adds overtones of safety and security. Thus the term's general concept is progression away from agitated movement and motion to a state of settlement marked by stability and security. Any conception of rest must include the associated ideas of a state of settlement and security marking the end of an agitated state of movement. In reference to נוח, Berry goes so far as to say, "I doubt if the meaning rest from work is found anywhere in the Old Testament." $" 71$

Several passages illustrate the point that most properly describes a cessation of motion. As seen above, YHWH caused Israel to "settle down" (נוח)

67 Keil, Pentateuch, 399; Berry, "Hebrew Word," 209; Westermann, Genesis 1-11, 173; Childs, Exodus, 416; Enns, Exodus, 419; Miller, Ten Commandments, 124.

68 Gnana Robinson, "The Idea of Rest in the Old Testament and the Search for the Basic Character of the Sabbath," ZAW 92/1 (1980): 33.

69 Leonard Coppes, "נוח," TWOT, 562.

70 John Oswalt, "נוח," NIDOTTE, 57.

71 Berry, "Hebrew Word," 207. 
in the Promised Land (Deut 12:10; Josh 21:44; 23:1). Their "rest" was not from daily labour; it was from the rigours of constant warfare. When the conquest was completed they were free to settle down in their inheritance. Furthermore, the settlement described by נוח is not always physical. It can also be relief from suffering or mental unrest: ${ }^{72}$

- Isaiah 14:1-3 describes reprieve from suffering, using נוח twice in the process. Isaiah 14 depicts Israel's deliverance from foreign oppression. Verse 1 uses נוח in a physical sense of settlement in the land and then says in vv. 3-4, "When the Lord has given you rest [נוח] from your pain and turmoil and the hard service with which you were made to serve, you will take up this taunt ..." The turmoil from which they are settled can be described as "trouble which torments." 73 While labour is obliquely referred to in "hard service," it should be noted that this is not every day work; it is work occasioned by the torment of captivity.

- Proverbs 29:17 describes mental quietness: "Discipline your son, and he will give you rest [נוח]; he will give delight to your heart." The first strophe portrays settlement as the result of a child who is disciplined. The second strophe makes the mental quietness clear sharpening the idea of settlement as "delight" of the heart. ${ }^{74}$

A notable example is Gen 49:15, in which Jacob's blessing of Issachar describes rest in the midst of labour:

He saw that a resting place [מְנִחד] was good, and that the land was pleasant, so he bowed his shoulder to bear, and became a servant at forced labour.

In this instance a nominal form of נוח is used to describe a place of rest. Far from being the absence of work, this rest is in the context of forced labour. Issachar will choose it because settled life in the Promised Land is a positive situation, even if it involves forced labour. ${ }^{75}$

The ideas of rest presented by the first creation account and Exod 20:11 are not dissimilar. Genesis 2:1-3 uses שבת to describe God's rest, a term that primarily describes cessation from a particular activity. The use of נוח in Exod

72 Berry, "Hebrew Word," 207.

73 John Oswalt, The Book of Isaiah, Chapters 1-39 (Grand Rapids: Eerdmans, 1986), 311.

74 Bruce Waltke, The Book of Proverbs, Chapters 15-31 (Grand Rapids: Eerdmans, 2005), 445.

75 Robinson, "Idea of Rest," 35. 
20:11 describes a cessation of movement or a settling down into a stable environment. Thus the seventh day of Gen 2 and the description of it in Exod 20 are both marked by cessation from a particular labour, but Exod 20 further specifies that it was also meant to be enjoyed in an environment of stability and safety. The use of נוח in Exod 20 also suggests something else: it is not general "rest" advocated by the fourth commandment. It is rest from humanity's customary work that is marred by the curse of Gen 3. It says nothing of the work done by humanity in the garden prior to those events.

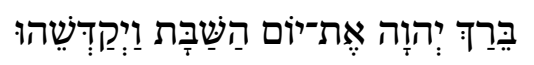

"YHWH blessed the Sabbath day and he sanctified it" (Exod 20:11).

The word order found in Exod 20:11 is the reverse of that which is found in Gen 2:3. There, God blesses and sanctifies the day and then provides the reason for his actions. Exodus 20:11 begins with YHWH's creative activity and ends by describing the blessedness and sanctification of the seventh day. The reversal forms an inclusio and ends the fourth commandment where it began in $20: 8$, with the sanctification of the seventh day. Israel is to sanctify the seventh day as YHWH has sanctified the seventh day. The observations made in a previous article concerning Gen 2:3a $\mathrm{a}^{76}$ apply here as well. The Sabbath day is marked by its unique relationship to YHWH, functioning in a way that no other day functions. It is differentiated as a unique day of cessation. The Sabbath commandment's significance is bound up in the idea that it is YHWH's unique day, just as the seventh day at the end of his creative activity was unique. ${ }^{77}$

\section{CONCLUSIONS}

Our examination of Exod 20:8-11 has sought to understand the fourth commandment in light of the Decalogue's place at the head of the law and, in turn, the law's place within Israel. We have also sought to read it with an eye to the overall calling and purpose of Israel in the midst of the nations. These examinations are suggestive of four primary conclusions:

First, the Sabbath commandment should be understood against the backdrop of Israel's purpose. YHWH redeemed Israel so that she could proclaim YHWH's goodness and superiority over all other gods. As a kingdom of priests, their ministry was bi-directional. Israel was to bring the knowledge of God to the nations and the nations had the opportunity to come to God through Israel.

\footnotetext{
76 Haynes and Krüger, "Creation Rest: Genesis 2:1-3."

77 Keil, Pentateuch, 399.
} 
Second, the Sabbath commandment should be understood in relation to the Decalogue's purpose in the life of Israel. Additionally, its relationship with the rest of the law should be born in mind. The moral boundaries of the law reflect righteous living. Keeping the law would display the care and concern for YHWH and one another that marked seventh-day life. Motivationally, YHWH was concerned that law-keeping express inward gratitude and love for him. He had redeemed them from bondage in Egypt and was about to place them in the Promised Land, which was itself a recapitulation of the garden. Their lawkeeping was not intended to be merely external, but the overflow of a grateful heart.

Third, the nuances of particular aspects of the commandment itself must be recognised. Exodus' version of the Sabbath commandment is grounded in the first creation account and reflects God's rest on the seventh day. The command to remember demanded more than a cognitive understanding; it required the external action of ceasing from regular work (i.e., customary labour) as well. Covenantal overtones associated with "remembering" imply that properly observing the Sabbath day was required to maintain the covenant with YHWH. Furthermore, the purpose of their remembering was to sanctify the day as something different from the other six days, a day uniquely belonging to God and set apart (and thus holy) for his use.

While the fourth commandment uses the term נוח instead of שבת, these two terms speak to similar circumstances. God rests from his creative acts on the seventh day. In the fourth commandment humans are commanded to rest from their customary labour. The reason for this is that humanity's customary labour is marred by the curse of Gen 3. Lamech cried out for this rest when he named his son Noah. Rest from curse-ridden work thus recalls how things stood on the seventh day and suggests that the work proscribed by the fourth commandment does not include humanity's work prior to the events of Gen 3.

Finally, we see that Sabbath rest is not something that belongs uniquely to Israel. Because it is grounded in creation and the shared history of humanity, it belongs to everyone. Additionally, humanity's actions after the events of Gen 3 continue to have a negative effect on both animals and land. Therefore, slaves, aliens and livestock are included in the rest that the Sabbath provides. Its ongoing trajectory will eventually include the land as well because all need relief from the effects of the curse. As Westermann ${ }^{78}$ reminds us, the primeval history is not something unique to Israel, but rather grounds Israel's history in the history of all humanity and the very created order itself.

78 Westermann, Genesis 1-11, 65. 
The Sabbath is bestowed not simply because YHWH rested on the seventh day. It is bestowed because humanity now labours under a curse that makes toil wearisome and difficult. The rest offered by the Sabbath is not meant to signal a general period of leisure, but a reprieve from curse-ridden work. In the first creation account it was specifically God who enjoyed seventh-day rest. There, humanity did not rest in the same way that God did on the seventh day. Our study of Exod 20:8-11 bears this out. If Israel can be said to imitate YHWH in the Sabbath commandment, it is in the fact that they rest from a particular kind of work. Just as God ceased from his creative work on the seventh day and "rested," so Israel ceases from curse-ridden work on the Sabbath.

When these conclusions are read against the backdrop of the seventh day of creation, a few further theological conclusions present themselves. The weekly Sabbath intends to grant a taste of what life was like for humanity living in the Garden of Eden. It points to a time when humanity laboured before God and enjoyed intimate fellowship with him. Further, YHWH expected Israel to keep the law as a reflection of their heart-attitude towards him. In particular, the Sabbath commandment stood as a strong indication of their inward affection. This is why it served as a sign of the covenant as a whole. If Israel were to keep the Sabbath with a whole heart they would, in effect, be saying, "Yes! We long to enjoy life and relationship with YHWH as it was enjoyed at the end of the creation week. We want to fulfil our mandate to reflect life on the seventh day to the nations of the world." This was, in fact, the whole point of Israel's mission and purpose before God: to be a kingdom of priests and a holy nation. Motivationally speaking, Sabbath-keeping thus impacts humanity in three ways. First, it reminds humanity of what life once was in the garden and what was lost with the events of Gen 3. Second, it looks forward to what life will be again one day. The new heavens and the new earth will come and God's people will once again enjoy seventh-day living with him. Third, it allows humanity to enjoy the creator in the present, remembering what once was and living in hopeful anticipation of what will be.

With this in mind, it can be said that the theological underpinnings of the Sabbath commandment in Exod 20:8-11 are broad and grand. Humanity does follow God's pattern of rest on the seventh day, but the depth of thought it conveys goes far beyond that. It is a pointer to the function and relationship that humanity enjoyed with God in the Garden of Eden.

\section{BIBLIOGRAPHY}

Beakley, David. 'God's nhm ('Comfort') as the Unfolding of God's Promise in Four Old Testament Historical Passages." PhD Thesis, North-West University, 2014. Berry, George. “The Hebrew Word חנוּ." JBL 50/3 (1931): 207-10. 
112 Haynes \& Krüger, “Creation Rest,” OTE 31/1 (2018): 90-113

Black, Matthew. Romans: Based on the Revised Standard Version. Grand Rapids: Eerdmans, 1973.

Block, Daniel. Deuteronomy. NIVAC. Grand Rapids: Zondervan, 2012.

Bruckner, James. Exodus. NIBCOT 2. Peabody, MA: Hendrickson, 2008.

Childs, Brevard. Exodus: A Commentary. London: SCM, 1974.

Christensen, Duane. Deuteronomy 1:1-21:9. Rev. ed. Nashville, TN: Thomas Nelson, 2001.

Clines, David, ed. The Concise Dictionary of Classical Hebrew. Sheffield: Sheffield Phoenix. 2009.

Collins, C. John. Recurring Biblical-Theological Issues in OT Studies. Unpublished, 2005.

. Genesis 1-4: A Linguistic, Literary, and Theological Commentary.

Phillipsburg, NJ: Presbyterian \& Reformed, 2006.

Cotterell, Peter and Max Turner. Linguistics and Biblical Interpretation. Downers Grove, IL: Intervarsity. 1989.

deVaux, Roland. Ancient Israel and its Life and Institutions. London: Darton, Longman \& Todd, 1961.

Durham, John. Exodus. WBC 2. Waco, TX: Word, 1987.

Eder, Asher. "The Sabbath Commandment: Its Two Versions." JBQ 25/3 (1997): 18891.

Enns, Peter. Exodus. NIVAC 2. Grand Rapids: Zondervan, 2000.

Harris, R. Laird, L. Archer Gleason, and Benjamin Gladd, eds. Theological Wordbook of the Old Testament. 2 Vols. Chicago, IL: Moody. 1980.

Haynes, Matthew and Paul Krüger. "Creation Rest: Genesis 2:1-3 and the First Creation Account." OTE 30/3 (2017): 663-83.

Joüon, Paul and Takamitsu Muraoka. A Grammar of Biblical Hebrew. 2nd ed. Rome: Gregorian \& Biblical Press, 2011.

Keil, Carl. The Pentateuch. Peabody, MA: Hendrickson, 1866.

Koehler, Ludwig and Walter Baumgartner, eds. The Hebrew and Aramaic Lexicon of the Old Testament. Translated and edited under the supervision of Mervyn E. J. Richardson. 5 Vols. Leiden: Brill. 1994-2000.

Kraeling, Emil. "The Interpretation of the Name of Noah in Gen. 5:29." JBL 48/3-4 (1929): 138-43. https://doi.org/10.2307/3259720

Lust, Johan, Erik Eynikel, and Katrin Hauspie. A Greek-English Lexicon of the Septuagint on CD-ROM. Accordance Library System Version 2.5., 2017. Print ed.: Stuttgart: Deutsche Bibelgesellschaft, 2003.

McConville, J. Gordon. Deuteronomy. ApOTC 5. Downers Grove, IL: Intervarsity, 2002.

Miller, Patrick D. "The Place of the Decalogue in the Old Testament and its Law." Int 43/3 (1989): 229-42. https://doi.org/10.1177/002096438904300302

. Deuteronomy. IBC. Louisville, KY: John Knox, 1990.

. The Ten Commandments. Louisville, KY: Westminster John Knox, 2009.

Oswalt, John. The Book of Isaiah, Chapters 1-39. NICOT. Grand Rapids: Eerdmans, 1986.

Robinson, Gnana. "The Idea of Rest in the Old Testament and the Search for the Basic Character of the Sabbath." ZAW 92/1 (1980): 32-42. https://doi.org/10. 1515/zatw.1980.92.1.32 
Ross, Allen. Introducing Biblical Hebrew. Grand Rapids: Baker Academic, 2001. Sklar, Jay. Leviticus. TOTC 3. Downers Grove, IL: Intervarsity, 2014.

Stuart, Douglas. Exodus: An Exegetical and Theological Exposition of Holy Scripture. NAC 2. Nashville, TN: Broadman \& Holman, 2006.

Swanson, James A. A Dictionary of Biblical Languages with Semantic Domains: Hebrew (OT) on CD-ROM. Accordance Library System Version 7.0., 1997.

VanDrunen, David. Divine Covenants and Moral Order: A Biblical Theology of Natural Law. Grand Rapids: Eerdmans, 2014.

VanGemeren, Willem, ed. New International Dictionary of Old Testament Theology \& Exegesis. 4 Vols. Grand Rapids: Zondervan. 1997.

Waltke, Bruce. Genesis: A Commentary. Grand Rapids: Zondervan, 2001. . The Book of Proverbs, Chapters 15-31. NICOT. Grand Rapids, MI: Eerdmans, 2005. . An Old Testament Theology: An Exegetical, Canonical, and Thematic Approach. Grand Rapids: Zondervan, 2007.

Walton, John. Genesis. NIVAC 1. Grand Rapids: Zondervan, 2001.

Westermann, Claus. Genesis 1-11: A Commentary. Translated by John J. Scullion. Minneapolis, MN: Augsburg, 1984.

Westermann, Claus and Jenni, Ernst, eds. Theological Lexicon of the Old Testament. 3 vols. Peabody, MA: Hendrickson. 1997.

Williams, Michael. Far as the Curse is Found: The Covenant Story of Redemption. Phillipsburg, NJ: Presbyterian \& Reformed, 2005.

Williams, Ronald. Williams' Hebrew Syntax. 3rd ed. Toronto: University of Toronto Press, 2007.

Wolters, Albert. Creation Regained: Biblical Basics for a Reformational Worldview. Grand Rapids, MI: Eerdmans, 2005.

Wright, Chris. Old Testament Ethics for the People of God. Downers Grove, IL: Intervarsity, 2004.

. The Mission of God: Unlocking the Bible's Grand Narrative. Downer's Grove, IL: Intervarsity, 2006.

Rev Matthew Haynes, PhD (candidate), North-West University. He is also an adjunct OT lecturer at the Bible Institute of South Africa, 180 Main Road, Kalk Bay, 7975, near Cape Town, RSA. Email: mbhaynes@ bisa.org.za. ORCID ID: https://orcid.org/0000-0003-1503-5962

Prof Paul Krüger, Emeritus associate professor of Old Testament, Faculty of Theology, North-West University; currently extraordinary researcher, Unit for Reformational Theology and the Development of the SA Society, North-West University. Private Bag X6001, 2520 Potchefstroom, RSA. Email: paul.kruger@nwu.ac.za. ORCID ID: https://orcid.org/0000-0002-0847-6527. 